\title{
The Increase of Swimming Distance Ability Using Tools for Flippers \& Back Buoys and Kickboard on Freestyle Swimming Learning for Sports Science Students Beginners
}

\author{
Badruzaman Badruzaman* \\ Department of Recreation and Health Education, Faculty of Sport Education and Health \\ Universitas Pendidikan Indonesia \\ Bandung, Indonesia \\ *badruzaman@upi.edu
}

\begin{abstract}
The purpose of the study was to increase the ability of swimming distance freestyle between those who used Flippers $\&$ back buoy, kickboard aids and those without using tools. Methode; used true experiment, pre-test and post-test design with the control group, and determined randomly assignment devided into group. Participant; 30 student sport science who is taking a swimming study in semester III, class of 2017. Instrument; use the freestyle swimming test with distance measurements achieved. Analysis; using T test and ANOVA one way, followed by aposteriori test Scheffee technic. Result; based on $t$ test there are significant differences swimming distance ability between pretest and postets results for the three group. Those who use flippers \& back buoy have more capabilities than thos who use kickboard and those without use aid. Ftest results, between the three group there are significant differences in swimming distance ability by $F$ count $=24.15>$ Ftable $=5.42$ at $\alpha=0.01$. Result aposteriori test, the difference in the mean wich shows significant between which use flippers \& back buoy and without used aid by dispute mean $=19>$ than value critical value $=11.02$ at $\alpha=0.05$. That is, using a flippers \& back buoy, more effectively increasing the ability of the swimming pool comparated to using kickboard and which do not use tools.
\end{abstract}

Keywords-distance swimming ability; freestyle; buoy aid; flippers \& back float; kickboard

\section{INTRODUCTION}

Having swimming abilities for someone is a very important need to protect yourself from the dangers of accidents drowning in water. Having the ability to swim may also prevent a person from fatal drowning accidents. Conventional wisdom has suggested that teaching is the most important thing to do with drowning prevention interventions [1]. There are many facts that people die because of drowning because they cannot swim. Despite these efforts more than 400,000 people worldwide drown every year from a variety of couses, including in swimming inability [2]. A decade ago, Brenner and colleagues in 2006 recommended that "the concept of swimming ability should be replaced by more than not possible competence" (p. 116) [1]. Meanwhile, based on swimming teaching experience for 33-year-old beginners, there are still many facts found by people who have not been able to swim as in each class of non-Faculty of Sport students.
To prevent accidents from drowning, everyone must be taught to swim from an early age. Parents can be better teachers because, who may be better to teach you to swim than the person you trust? Parents can establish an optimal environment for learning for children ages 6 months to 4 years [3]. The ratio between multilateral and specialized training has been to be carefully planned, conclusively the fact that in contemporary sports there is a high level of performance (i.e., gymnastics, swimming and even figure skating). No one is more likely to see children two or three years of age in the swimming pool [4]. Actually the physical education program at school has included swimming learning programs from kindergarten to college, but it has not been able to produce all students able to swim. This can be caused by various factors that influence it. Can be caused due to the internal factors of the student itself, or the program's learning process that is less effective. But based on interviews with several failed students, they almost all said they had fear of water.

Swimming skills are classified as sports that have a level of difficulty to learn, especially for people who have a fear of water, and have limited basic mobility. Swimming as an activity in water is more difficult to carry out movements than on land activities. In water it requires special biomechanical principles in water to float and move easily. Swimming differs from other types of sports in several aspects. The firs and maybe the most obvious difference is the peculiar substance of water. Submerged in water, the student is exposed to physical effects that he cannot experience during other motor activities. Swimming like teaching motion differs from other land sport activities. The reasons for this specialty are the uniqueness of the substance of water, its effect on teaching swimming and special biomechanical principles that don't occur in land [5].

The problem of student difficulties in the swimming learning process, requires a variety of effective didactic approaches so that the problem can be solved. And didactic is the responsibility of the instructor to find a solution, so that those who still cannot swim, can be upgraded or minimized. Each instructor is required to pay more attention and help students who have weaknesses or deficiencies in terms of their abilities, so they can better adapt to other students to participate actively in the learning process. Based on observations, 
students who have skills weaknesses in water, almost all of them are less active in participating in teaching assignments. As instructors, it has the responsibility to maintain the safety of students from various hazards of accidents, especially in the water that is quite patal if it does not provide close supervision. Teaching and learning are the necessary modifications to the safety of the teacher and learner relationship and also certain communicational channels [6].

And the teacher also has a duty not to ignore students who have weaknesses that cause limitations in their abilities. In the learning process, the teacher must try to include all students to actively learn. So for students who are seen as slow and have difficulties, during the learning process, one of them must be given assistance with a buoy. Various types of aids are used instead of direct practice for the learning of complex motor skills. These aids allow students to practice skills that otherwise might be impossible to learn under the equipment and facility limitations [7]. The tools in the process of learning to swim are many kinds; Step to success: kickboard, leg float, face mask, swim fins, snorkel, deep float, float belt, buoyancy belt, hula hoop [8]. In addition to these aids, there are also those that often appear to be used in training sites such as; hand paddles, pull-bouys, stick float, back float. But these tools cannot be used carelessly, they must be used according to their functions and needs. Even tools that are not suitable for use can interfere with movement or are less effective. There are many swimming aids on the market today. While some help with learning processes along, others may be important because you can become too reliant on them. Flippers (fins), kickboards, and pullbuoys are valuable because they help you keep horizontal in the water [9]. In the effort of education, it is necessary to review each equipment as well as possible, not to let the tool itself hinder the achievement of the goal. The selection of tools that are careless or inappropriate, it will be an obstacle in achieving educational goals. Therefore, the teacher must choose an educational aid that is in accordance with the education and teaching objectives that have been formulated [10]. Our purpose is to suggest and demonstrate how you might use material to design effective solutions to the variety of instructional challenges you are apt to face in the future [11].

The tools tested in this study are; flippers, back float, and kickboard. These tools will help students increase selfconfidence, increase courage, prevent drowning, and provide convenience in performing motion techniques. For researchers, choosing flippers and back floats, especially in freestyle learning, back floats are tied to lock with buckles and placed behind the back giving a sense of security or safety so as not to sink during the learning process. Also the back float can increase buoyancy to lift the swimmer's body awake above the water surface, because in the freestyle the posture must be maintained in a horizontal position. Flippers are given to support the legs so that they do not easily bend their knees so that the foot position is kept straight. And using flippers, the thrust is greater, so the speed is faster. With faster speed, the effort to push the arm is lighter, so that you can do arm movement techniques more easily. Hines Emmett, Flippers/Fins extend your feet and legs, making your kick faster and more efficient. They help increase ankle flexibility and leg strength, and they also activate more muscle mass, you will not be working on. Plus, you'll find that the extra speed that you provide when you swim is simply lots of fun [12]. Wearing flippers is useful because it helps to keep your body horizontal in the water, and give you greater flexibility, especially in the ankles. This flexibility is essential for kicking movements, where flippers act as an extension of yours legs, pushing you more forcefully through the water [9]. These two tools are expected to make students more calm, comfortable during the learning process and able to actively participate in teaching assignments every given. With an effective learning process, mastery of the skills taught can be achieved. Kickboards are used as imperative in order to concentrate on kicking motions without worrying about keeping the upper body afloat. It is used by beginners and advanced swimmers alike." [13].

Previous research on a college group beginning with swimmers, using a waist-type floatation device, was able to swim in a more comfortable way than a group taught without it. Flotation devices are used in swimming to overcome fear of water, as well as to facilitate the learning of swimming skills. However, there is still a very little scientific experimental work to analyze the effectiveness of transmission in teaching devices [7]. Siedentop; emphasizes the need to maximize the time the learner is practicing task (time-on-task) and the need for the task to be appropriate for the level of the learner [14]. During the guidance exercise that is assisted with tools, it facilitates their appearance. But when the device is released, the group assisted by the device appears worse. But in his recommendation, he said, that does not mean that training is aided by a tool, it cannot be used again in the process of motion training. The advantage remains, if this method is applied to two conditions namely;

In very early practice, when students are developing the most difficult motion assignments, guidance procedures with tools become useful. To avoid dependence, this procedure should be changed quickly, i.e. when the student can perform the task independently.

Dangerous task. Like a belt buckle in gymnastic learning, this can be done to prevent injury. But when it has begun to increase in capacity, the level of assistance is gradually reduced. In this case, guidance with these tools has other benefits, namely to reduce fear or doubts from students, as well as increasing confidence [11].

A case study in rural China has found that swim instruction provide a protective effect on drowning among children age 14 years. Supporting evidence also has been reported in high income countries (HICs). A case-control study in the U.S. found a positive association between swimming lessons and lower drowning risk in children less than five years old [1] Indicated that programs that rely on using buoyance instruments influence positively on the level standing in water, and performance legs alternative strokes for $(12.5 \mathrm{~m})$, swimming for $(15 \mathrm{~m})$ and effectiveness of aid instruments in getting rid of fear factor and speed in learning swimming [15]. For experimental group research in an attempt to recognize the effect of using instruments of buoyancy on the level of performing some basic skills in swimming and some physiological variables. For female student (experimental research sample) to using the suggested educational program by using aid buoyancy instruments that contribute greatly is learning swimming basic skills quickly and in a good way, by education process regularity within educational lecture, this influenced positively on level of physiological traits [15]. The didactic tools most frequently used during the swimming classes include kickboards, floating noodles and pool dive toys. 
Analysis of the results shows that in swimming schools the three most frequently used didactic tools include a kickboard (4.24), a floating noodle (4.11) and pool dive toys (3.60). Of all the above mentioned swimming aids the professionals only rarely used mats and slide, whereas swimming balls and swimming belts are almost never used [16]. A Learn-to-swim program using a personal flotation device or a floating vest decreased the incidence of surface diving by children during free play that had used the vest during instruction compared to the amount of surface diving undertaken by children who were taught without flotation [17].

\section{METHOD}

\section{A. Participant}

Participants are 30 students (25 male) (5 female) Sports science on the Faculty of physical education Sport and health, Universitas Pendidikan Indonesia. Taken from two classes in the third semester of 2017. The age range is between 18-20 years. All samples on average prates have swimming abilities up to a distance of $4.5 \mathrm{~m}$. Samples are taken by block technique and random assignment. The sample was divided into three groups, each group filled 10 people randomly determined and taught with two different methods. Group assignments by observing the pratest results by looking at three levels of ability; highest, middle and lowest levels. The highest level is placed in a different group, and so is the lowest level. Medium ability is randomly assigned to be included in the three different groups [18].

TABLE I. PRETEST-PostTEST RESEARCH EXPERIMENT DESIGN WITH CONTROL GROUP

\begin{tabular}{|l|l|l|}
\hline O1 (Pretest) & $\begin{array}{l}\text { X (experiment) using } \\
\text { Flippers \& Back float }\end{array}$ & O2 (posttest) \\
\hline O3 (Pretest) & X (experiment) using kickboard & O4 (posttest) \\
\hline O5 (Pretest) & X (experiment) Control without a tool & O6 (posttest) \\
\hline
\end{tabular}

\section{B. Instrument}

The instrument uses the freestyle swimming ability test for beginners based on the swimming distance product that was successfully reached. To determine the aspects of performance to access, you need to consult instructional manuals or books that contain information about the components of the tasks you learner is attempting to acquire. The components you select should include both process characteristics (e.g., movement form) and outcome scores (e.g., distance from the target, movement time) [11]. The test was conducted twice in the pretest and post-test for the three groups. The swimming pool for the test is prepared with a 25 meter long one-way pool for pretest, and in post-test with two way $(50 \mathrm{~m})$. The depth of the collage is $1.80 \mathrm{~m}$, the water temperature ranges from 24 degrees. Measurements using system metrics, namely meters, by giving tana-signs on the edge of the pool for every one meter. The American Red Cross has developed a hierarchy of swimming skills that reflect criteria-refined standards for beginner skills: 1 . breath holding-10 seconds, 2. Rhythmic breathing --- 10 seconds., 3. Prone glide, 4. Back glide, 5. Prone glide with kick, 6. Back glide with kick, 7. Beginner stroke or crow stroke - 15 yards, combined stroke on back --15 yards [19]. The instrument uses the freestyle swimming ability test, using the mileage measurement system achieved by swimmers with the metric system. The fundamental unit for distance in the metric system is the meter (m) [20].

\section{Procedure}

The location of the study was conducted in the swimming pool of the Indonesian Education University. The study was conducted during the lecture swimming practice given for 14 weeks, plus two meetings for pre-test and post-test. Every learning is done with duration of 90 minutes. Each meeting begins with warming-up ranging from 10-15 minutes, core learning 60 minutes, and closing and evaluating 15 minutes.

- The first week; before being given treatment, a pre-test was carried out with a choice of swimming styles for all students. The pre-test is carried out in the swimming pool with chest-deep water depth. This test is intended to see the basic ability of swimming at a distance of 25 meters. Students who did not reach the distance were separated from those who managed to reach a distance of 25 meters. Then there were 42 failed students out of a total of 120 people. Of the 40 people taken to make a sample of 30 people, determined randomly and pay attention to the results of the pre-test. All samples were entered into three groups equally in their initial abilities, so that the average initial ability of each group was almost the same, namely $4.5 \mathrm{~m}$. One group was used as a control group that was not given a tool, and the other two groups were taught by using different tools, namely fleppers \& back float and kickboard

- Second week; Still in the shallow pool $(1.2 \mathrm{~m})$ each group was given treatment to be taught free style, with a given aid (Flippers and back float) for the first group (A), group (B) with Kickboard, and group (C) as the control group doesn't use it.

- The first stage all participants are taught to slide using each of the tools provided except the control group. Then taught the freestyle legs first without moving by holding the pool lip. Then proceed while moving sliding plus foot movements. All focus on leg exercises.

- The third week; the second stage, taught the freestyle arm movement technique done first on land, then continued in the water by staying in place while bending. Arm movement pattern when doing pull and push movements, its position is inside the water surface.

- The fourth week; the third stage is taught arm movements while moving gliding, then do the pattern of arm movements without taking a breath. Arm movements are done as hard as possible without taking a breath.

- The fifth week; the fourth stage is the coordination of legs and arms, without taking a breath.

- The sixth week; the fifth stage is taught coordination of arm movements by taking breath in place, continued while moving.

- The seventh week; the sixth stage applies movement of the legs, arms and breath.

- The eighth week; the seventh stage repeats the coordination of legs, arms and breath. 
- The ninth week; the stage for continuing complete coordination learning, while monitoring the smoothness of taking breath.

- The tenth week; the eighth stage, gradually reducing or releasing a tool according to its readiness. Students who feel their readiness to be reduced or completely released, then practice without using tools.

- The eleventh week; the ninth stage, complete coordination learning continues by monitoring its smoothness, and gradually reducing the tools it uses.

- The twelfth week; stage ten, try to release all the tools used, and do freestyle swimming. Although there are still some who are not fully prepared.

- The thirteenth week; stage eleven, repeating freestyle swimming exercises without tools.
- The fourteenth week; posttest for all participants by measuring the distance traveled. Performed in ponds as high as $1.8 \mathrm{~m}$.

\section{Analysis}

Arithmatics mean, standard deviation, despite the mean, and minimum rating. Analysis is inferior to Test, one way ANOVA, and aposteria test with Scheffee technique [21].

\section{RESULTS}

After calculating from the collected data either through $\mathrm{T}$ test analysis, one way ANOVA, and post hoc test, the results obtained are presented in the following tables;

T-test of Pre-test and Post-test Results between Using Flippers \& Back Floats, Kickboards, and without tools.

Based on the results of statistical calculations both differential and inferential, the data can be seen in table 2 below.

TABLE II. RESULTS

\begin{tabular}{|l|l|l|l|l|l|l|l|l|l|}
\hline $\begin{array}{c}\text { Variables } \\
\text { Floating Aid }\end{array}$ & $\begin{array}{l}\text { Subject } \\
\text { Sample }\end{array}$ & $\begin{array}{c}\text { Mean } \\
\text { pratest }\end{array}$ & $\begin{array}{c}\text { Mean } \\
\text { post test }\end{array}$ & $\begin{array}{c}\text { Mean } \\
\text { dispute }\end{array}$ & Sd & $\begin{array}{c}\text { Rate } \\
\text { postest }\end{array}$ & Tcount & Ttable & $\begin{array}{c}\text { Significance. } \\
\mathbf{0 . 0 5}\end{array}$ \\
\hline $\begin{array}{l}\text { Flippers \& } \\
\text { backfloat }\end{array}$ & 10 & $4.5 \mathrm{~m}$ & $31 \mathrm{~m}$ & $26.5 \mathrm{~m}$ & 2.6 & $20-40$ & 7.1 & 2.086 & Sig. \\
\hline Kickboard & 10 & $4.5 \mathrm{~m}$ & $22 \mathrm{~m}$ & $17.5 \mathrm{~m}$ & 2 & $15-30$ & 7.69 & 2.086 & Sig. \\
\hline $\begin{array}{l}\text { Not in use / } \\
\text { Control }\end{array}$ & 10 & $4.5 \mathrm{~m}$ & $12 \mathrm{~m}$ & $7.5 \mathrm{~m}$ & 4.5 & $5-25$ & 2.81 & 2.086 & Sig. \\
\hline
\end{tabular}

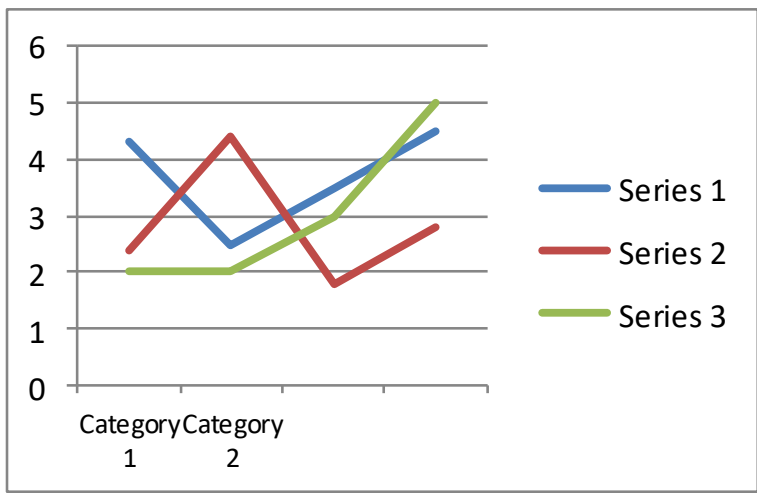

Fig. 1. The calculation results.

In table 2, the calculation results show that using flippers and back float tools have the farthest distance difference with a mean of $26.5 \mathrm{~m}$ compared to those using kickboard with mean $=17.5 \mathrm{~m}$ and control group mean $=7.5 \mathrm{~m}$. The shortest distance from the post test results using flippers \& back float $20 \mathrm{~m}$ and farthest $40 \mathrm{~m}$. The results of the $\mathrm{T}$ test show a significant difference with Tcount $=7.1>$ of $\mathrm{T}$ table $=2.086$ at $\alpha=0.05$. Thus, using a flippers \& back float tool has a significant influence to increase swimming ability at the distance traveled. Using kickboard, it has a difference in distance of $17.5 \mathrm{~m}$ between the results before and after the treatment is lower than those using flippers \& back float. The shortest distance range at post $15 \mathrm{~m}$ and the farthest one is at 30 $\mathrm{m}$. The results of the $\mathrm{T}$ test show a significant difference between the pre-test results and the posttest with the score Tcount $=7.69>$ rather than Ttable $=2.086$ at $\alpha=0.05$. The results of the calculation of the control group (not using) aids showed a mean difference of $7.5 \mathrm{~m}$, before the treatment was $4.5 \mathrm{~m}$, and after $12 \mathrm{~m}$. The shortest distance range is $5 \mathrm{~m}$ and the furthest is $25 \mathrm{~m}$. Although having the mean difference in the shortest swimming distance compared to the treatment group using the tool, the results of the $\mathrm{T}$ test showed significant differences with the value of Tcount $=2.81>$ rather than $\mathrm{T}$ table $=2.086$ at $\alpha=0.05$. This means that the results of learning without tools have an increase in the ability of swimming distance even though the shortest compared to those who use assistive devices. But the $7.5 \mathrm{~m}$ increase in achievement still has not succeeded in achieving the target width of the pool with a distance of $25 \mathrm{~m}$. That is, according to the facts after the swimming lecture has finished for one semester, there are still some students who have not been able to swim at a distance of $25 \mathrm{~m}$.

To see the significance of the differences in the results of the distance traveled by the three groups, a one-way ANOVA analysis was conducted. The results can be seen in table 3 below.

TABLE III. RESUlt OF F-TEST WITH ONE WAY ANOVA BETWEEN THE METHOD AND THE USE OF AID

\begin{tabular}{|l|l|l|l|l|l|l|}
\hline $\begin{array}{l}\text { Variance } \\
\text { Source }\end{array}$ & dk & SS & MS & $\begin{array}{c}\text { F } \\
\text { count }\end{array}$ & $\begin{array}{c}\text { F } \\
\text { table }\end{array}$ & Significance \\
\hline $\begin{array}{l}\text { Between } \\
\text { Group }\end{array}$ & 2 & 2817 & 903.5 & & & \\
\hline In Group & 29 & 1807 & 37.40 & 24.15 & 5.42 & 0.01 \\
\hline Total & 31 & 4824 & \multicolumn{3}{|l|}{} \\
\hline
\end{tabular}

Table 3 based on the results of the ANOVA analysis, there are significant differences between the distance achieved between groups with a calculated $\mathrm{F}$ value $=24.15>$ Ftable $=$ 5.42 at $\alpha=0.01$. That is, the three groups of students taught by 
different assistive methods showed significant differences in swimming distance abilities. To analyze the significance of each group, it was followed by a further test (aposteriori) with the Scheffee test technique. The result of the one-way ANOVA test on the abilities of the free style swimming using a method of employing different types of skills as tools showed significant differences. This is based on data in table 3. The results show that Ftest is in the value of 24.15 meanwhile $F$ table $=5.42$ at $\alpha 0.01$.

This means that all three instructional methods of the freestyle swimming with the help of the buoy as a helping tool showed significant differences in the freestyle swimming for Sport Science Students. However, in order to determine the method with better results in the ability of swimming, there was a test using post hoc or pasca ANOVA using Scheffee test.

TABLE IV. MEAN DifFERENCE DATA BETWEEN GRoups With METHOD OF USING FLOATING TOOLS

\begin{tabular}{|c|c|c|c|c|c|c|}
\hline Column & Aid & n & mean & K1 & K2 & K3 \\
\hline K1 & $\begin{array}{c}\text { Flippers \& Back } \\
\text { buoy }\end{array}$ & 10 & $31 \mathrm{~m}$ & 0.00 & $9 \mathrm{~m}$ & $19 \mathrm{~m}$ \\
\hline K2 & Kickboard & 10 & $22 \mathrm{~m}$ & & 0.00 & $10 \mathrm{~m}$ \\
\hline K3 & Control/not using & 10 & $12 \mathrm{~m}$ & & & 0.00 \\
\hline Total & & 30 & \multicolumn{4}{|l}{} \\
\hline
\end{tabular}

Based on table 4, the biggest mean was obtained by the group 1 (flippers \& back float) $=31 \mathrm{~m}$, in the second position was group 2 (kickboard) $=22$, position 3 group 3 (without aid/control) $=12$. The biggest differences of the mean score was by group 1 and 3 (The one that used flippers \& back float and without aid used) with a difference of $19 \mathrm{~m}$. The second biggest difference was between group 2 and 3 (using the back float and without aid) the difference amounted to $10 \mathrm{~m}$. Meanwhile the smallest difference was by group 1 and group 2(flippers \& back float and kickboard) with a difference of $9 \mathrm{~m}$.

TABLE V. RESUlTS OF TEST APOSTERIORIES WITH SCHEFFEE TECHNIQUES

\begin{tabular}{|l|c|c|l|}
\hline \multicolumn{1}{|c|}{ Resources } & Mean despite & $\begin{array}{c}\text { Critical } \\
\text { Score }\end{array}$ & Significance 0.05 \\
\hline $\mathrm{K} 1 \times \mathrm{K} 2$ & $9 \mathrm{~m}$ & 11.02 & Not signifcant \\
\hline $\mathrm{K} 1 \times \mathrm{K} 3$ & $19 \mathrm{~m}$ & 11.02 & Significant \\
\hline $\mathrm{K} 2 \times \mathrm{K} 3$ & $10 \mathrm{~m}$ & 11.02 & Not significant \\
\hline
\end{tabular}

From this post hoc test using Scheffee, a critical value of 11.02 was obtained. The mean score differences between group 1 and 2 (using flippers \& back floats compared to using kickboard) showed a difference score of $9 \mathrm{~m}$, which is <the critical value score which is 11.02 . It means that the sports science students' ability to do freestyle swimming is compared to using kickboard. The comparison in usage of flippers \& back float without buoy (Group 1 and 3) has a significant difference with value was 19> the critical value of 11.02 . That is, swimming learning using flipper \& back float tools has better results than those who do not use assistive devices. Between group 2 and 3 (using kickboard and without using aid) a not significant difference, with differences of score $=10 \mathrm{~m}$ <critical value $=11$. 02. It means that learning swimming using the kickboard tool does not have a significant difference in the results of the ability of swimming distance between students and those who do not use assistive devices.

\section{DISCUSSION}

Freestyle swimming learning process using flippers \& back float, kickboard, and without tools for beginners, based on the results of the T-test analysis, showed significantly different results between the pre-test and the post-test. The student group given the flippers \& back float tools had an increased ability to swim further with a mean $=31 \mathrm{~m}>$ than those using the kickboard mean $=22 \mathrm{~m}$. And those who were not given aids as a control group had a mean ability lower than $12 \mathrm{~m}$. This can be understood, because flippers can provide a stronger thrust than foot movements for the swimmer's body to advance faster. Flippers can also keep your feet from bending in easily, so that they are kept above the water level and the body is in a horizontal position. This will give the arm work to do a lighter push motion. So that arm motion techniques will be easier and lighter to do. Flippers/leg wears, and surface area of the feet; increase in propulsion of stroke [22]. Hagerman, et al. Fins/flippers were used for propulsion purposes, giving a feeling of being lifted and pushed forward more rapidly than in normal swimming. The swimmer's body is higher in the water, and his or her body rides are more smoothly and comfortably in water. The sensations of speed and flow are not, however, the main purpose for using fins. Rather, it is to help swimmers practice kicking and to work on perfecting strokes [13]. Therefore, by getting the thrust of the foot, the body moves faster, so the effort of the learning process/arm exercises is lighter or easier. Because of doing freestyle swimming, the pattern of arm movements and taking breath is quite difficult. Thus, the training process can be more active and effective.

Giving a back buoy tool that is placed on the back, to lift the body so that it is above the water level, and the body remains in the horizontal attitude. With a buoy paired behind the back tied firmly to the body of a beginner swimmer, it can increase self-confidence, comfort, calmness and the body to maintain its stability. Then the process of arm movement training is more convenient. The back buoy is one of the most important skills ever to be learned in swimming. It allows one to rest and breathe while floating. It requires almost no effort. It may save one's life in the event of an aquatic emergency. It also teaches how to balance the body in any position from vertical to horizontal, which allows for potential skills to be learned, and they help in overcoming fear, so they are considered as one of the important educational factors as well as their role in helping learners to vary education that stimulates learning tendencies to improve better performance [15]. A swimming aid helps one to float and stay horizontally in the water, while doing help is in the learning process [22]. The buoy has a function to raise self-confidence so someone can feel comfortable and safe [9]. The method of using kickboard tools in freestyle learning for student beginners, based on the results of this study has increased progress in swimming distance capabilities but still below the mean using flippers with a mean difference of $9 \mathrm{~m}$. Kickboard aids for beginners, based on observations during the learning process, it seems that students still get difficulties especially the position of the body is difficult to maintain in the position of the day. Because the position of the foot often drops down, the knee often bends too deeply and also lashes the legs too deeply. The kickboard held in front cannot help the foot rise to the surface. In fact, the swimmer's body position is often in a diagonal position, so that the movement of the arms to push the body to move forward becomes heavier. As a result, swimmers often stop due to fatigue. The kickboard held in front, sometimes seems to 
interfere with arm movements, because it must always be held and can also inhibit the body's forward movement.

The control group that did not use the tool, based on the mean results of the ability of swimming distance travelled mean $=12 \mathrm{~m}$. That is, the distance of swimming ability is still half of the target pool width of $25 \mathrm{~m}$. This can be understood, because as long as the learning process takes place, they often remain silent and cannot actively participate in the learning process. This is because they feel heavy to lift their bodies to the surface of the water, and do arm impulses. Because their bodies are too below the surface of the water, the posture is not horizontal. The process of learning without tools, the continuity of many learning processes, often stops because they appear exhausted. So that the frequency of refraction exercises is reduced. Thus the active effectiveness of learning is hampered, causing the implementation of the learning process of motion techniques to be very minimal. This will affect the mastery of motion techniques, as well as the development of physical abilities that can also affect appearance. The repeating principle becomes part of the practice. The moving task in swimming is until the learners are skilled and competent [23]. Bathgate, note that using aid is the instrument of the basic level of learning for swimming skills. On the contrary, for students who don't use floating equipment, they are psychologically appearing to be still covered by anxiety, confusion and are being afraid in the water [15]. Practice must be focused on useful influence through completing technique quality. The practice must be enough; the interval or number of repetitions must be improved to achieve the performance of highest technique quality. Therefore, good planning can avoid the need to avoid exhaustion concentration while performing tasks [23].

The learning process for beginners seems to relate to their effectiveness. Claims are that children are more confident in using a vast and more willing to try more challenging learning exercises. Secondly, a flotation vest is a child jump start, making it possible to start with the instruction of propulsive movement. Furthermore, the vest makes safety a lesser challenge in deep water, which means that beginner swimmers can do more exercises independently [19]. Thus, time should be available to practice repeatedly. Using floating equipment, active time for practice is more effectively utilized. The learning process or practice is to improve movement patterns such as leg, arm, and coordination while learning. This matter has been appropriately put by previous studies and scientific references by Wesel and Erfan [14], who indicated that programs that rely on using buoyancy are positive influence instruments on performance of legs and alternative strokes. The effectiveness of aid in getting rid of the fear factor and improving speeds in learning swimming.

\section{CONCLUSION}

Swimming skills as a sport that is quite difficult to master and has the danger of drowning accidents, requires tools to prevent the occurrence of drowning accidents, and helps students to make it easier to do the motion techniques taught. Without the help of a tool, they have many difficulties in carrying out the training process. Based on the results of the study with analysis, the test using flippers \& back buoys in the swimming learning process for student beginners has a significant difference compared to using kickboard aids or those that do not use tools. Increasing the ability of swimming distances to use flippers $\&$ back buoys has a mean greater than that which uses kickboard and those that don't. That is, using flippers \& back buoys in swimming learning for beginners has an increased ability to swim more distance than those who use kickboard and those who don't use it.

Based on the results of the F test analysis, between the three groups had a significant difference in effect on swimming learning outcomes in the ability of distance traveled. And based on the results of further tests (aposteriori) with the Scheffee technique, the difference in mean is significant between the mean of group 1 and the mean of group 3. That is, between those who use flippers \& back buoys with those not used. So thus, the process of swimming learning for beginners for students is more effective by using flippers \& back buoys rather than using kickboard or with those that don't use tools.

Implementation for physical education teachers in schools, swimming instructors and swimming coaches in swimming sports clubs, in teaching/training swimming for beginners who have difficulties in learning, should be provided with buoyancy aids that are firmly affixed to the body of students, especially to maintain and guarantee the safety of every student who has not been able to swim. A tool that can be used to maintain student safety is with a back buoy. Also this tool makes it easy for them to learn about motion techniques for both leg movements and freestyle arms because this tool does not interfere with the movement of the legs or arms. Especially for learning freestyle, give a tool for flippers to keep your legs straight, not easy to bend and stay in the position of horizontal. Also with flippers, the body's speed will move faster in the future, so that arm movements are lighter. Give flippers that are sized according to the age level of students, and prices are cheaper but comfortable. The size of the flippers that match the condition of the student's power so as not to be too heavy when pressed down.

\section{REFERENCES}

[1] R.K. Stallman, K. Moran, L. Quan, S. Langendorfer, From Swimming Skill to Competence: Towards a More Inclusive Drowning Prepention Future. International Journal of Aquatic Research and Education. Volume 10/ Number 2. 10-6, 2017.

[2] K.D. Berukoff and G.M. Hill, A Study of Factors That Influence the Swimming Performance of Hispanic High School Student. International Journal of Aquatic Research and Education, 2010, 4, 409-421. Human Kinetics, Inc., 2010.

[3] A.S. Elena, Methodology of Learning Swimming in The First Part of Life Through a Positive Approach. Journal of Sport Science \& Medicine. Ovidius University Annals, Series Physical Education and Sport/Science, Movement and Health, 2005.

[4] B. Bompa, Theory and Methodology of Training. USA: Kendall/Hunt Publishing Company, 1990.

[5] M. Bíró, E.N. Biróné, B. Fügedi, L. Révész, L. Szabó, L. Honfi, Teaching and Learning Strategies during Primary School Students Swimming Education, Emphasis on Interaction. Thesis. Semmelweis University. Doctoral School of Sport Science. Budapest, 2007.

[6] M. Bíró, E.N. Biróné, B. Fügedi, L. Révész, L. Szabó, L. Honfi, Examination of Teaching-Learning Process in Swimming applying Chaffers Syistem of Interaction caegories. Educational Research and Review Vol. 2 (4) p. 064-073, April 2007. Available online at http://www.academicjournals.org.ER R ISSN 1990-3839 (c) 2007. Academic Journal, 2007.

[7] R.N. Singer, Motor Learning and Human Performance, an Application to Moloi Skill and Movement Behaviors. New York: Macmillan, 1980.

[8] G.T. David, swimming, Step to Success. USA: Human Kinetic, 1989. 
[9] D. Sharron, Learn Swimming Weekend.london: Dorling Kindersley Limited, 1996.

[10] D.S. Bahri, Guru dan Anak Didik dalam Interaksi Edukatif. Jakarta: PT. Rineka Cipta, 2005.

[11] R.A. Schmidt and C.A. Wrisberg, Motor Learning and Performance USA: Human Kinetics, 2000.

[12] H. Emmett, Fitness Swimming. USA: Human Kinetics, 2008

[13] Hagerman, et al. Efficiency Swimming. USA: Simultanously Published, 1987.

[14] S. Daryl, Introduction Physical Education Fitness, and Sport California: Myfield Publishing, 1994.

[15] S.E.Z.A. Shimaa, The Effect float Tools on Sonic Basic Skills Performance in Swimming and Some. Physiological Va.ri.bel for Student, in Faculty of Psysical Education.International Journal Science, Movement and Health, Vol. XIV. ISSUE 1. Januari 2014.

[16] A. Pečaver, M. Pungeršek, M. Videmšek, D. Karpljuk, J. Štihec, M Meško, Analysis of Didactic Approaches to Teaching Young Children to Swimm. United States Sports Academy in Contemporary Sport Issues, General, Sports Exercise Science, Sport Studies and Sports Psychology. February 14, 2014.
[17] K. Per-Ludvik and M. Marcel, Movement Patterns in Free Water Play After Swimming Lessons With Flotation Aids. International Journal of Aquatic Research and Education, 2012, 6, 149-155. Human Kinetics.

[18] J.W. Creswell, Research Design, Pendekatan Kualitatif, Kuantitatif, dan Mixed. Yogyakarta: Pustaka Pelajar, 2013.

[19] Baumgartner and Jakson, Measurrement for Evaluationin Fhyical Educationand and Exercise Science. USA: Brown Communication. 1995.

[20] Kirkendal, Measurement and Evaluation for Physical Educators. USA Brown Company, 1980.

[21] Supratiknya, Statistik Psikologi. Jakarta: Grasindo, 2000.

[22] T. Spigelman, A. Sciascia, T. Uhl, Return to Swimming Protocol for Competitive Swimmers: A Post-Operative Case Study and Fundamentals.Rehabilitation Sciences Faculty Publications, University of Kentucky nowledge. http://unnowledge.uky.edu/rehabsci_facpub. 2014 .

[23] Lutan, Belajar Keterampilan Motorik, Pengantar Teori dan Metode. Jakarta: Departemen Pendidikan dan Kebudayaan, Direktorat Jenderal Pendidikan Tinggi, 1998. 